\title{
Optimism: A Good Theme for Family Medicine
}

"What seems to us as bitter trials are often blessings in disguise."

-Oscar Wilde (Irish poet, novelist, dramatist, and critic, 1854-1900)

Dr. Pugno's commentary ${ }^{1}$ provides a good case for continuing to believe in the specialty of family medicine-optimism can spread optimism. Katerndahl et al's ${ }^{2}$ article about perceived complexity of care, autonomy, and career satisfaction is consistent with Dr. Pugno's thesis. First, most primary care physicians in the study were satisfied with their primary care careers. Most felt they could make autonomous medical decisions, and this was important to their satisfaction. However, the practice environment was more important than physician perception of complexity or autonomy. The availability of health care support services such as physical therapy, home health, and mental health services were associated with higher satisfaction, probably because being able to get patients the care they need makes physicians feel better, too. Group practice physicians were more satisfied than solo physicians. Physicians who felt the complexity was higher than desirable were less satisfied across the 3 specialties of family medicine, internal medicine, and pediatrics. Note that this was a perception of complexity, not measured complexity. We know that physicians can be trained to deal with multiple concurrent problems, thereby potentially enhancing their ability to deal with complexity and the sense of whether or not it felt like "too much." Still, only approximately $12 \%$ of the variance in satisfaction was explained through all the variables. Perhaps thinking more positively could help the $20 \%$ of physicians who were dissatisfied.

$$
\begin{aligned}
& \text { "Pessimism leads to weakness, opti- } \\
& \text { mism to power." } \\
& \text {-William James (American } \\
& \text { philosopher and psychologist, leader } \\
& \text { of the philosophical movement of } \\
& \text { Pragmatism, 1842-1910) }
\end{aligned}
$$

Some of the perceived complexity noted by Katerndahl et $\mathrm{al}^{2}$ is related to patients that physicians report as "difficult." As reported by Elder et $\mathrm{al}^{3}$ in a previous issue of the Fournal of the American Board of Family Medicine ( $A A B F M)$, "studies examining physician characteristics have found that physicians with lower job satisfaction, less experience, and poorer psychosocial attitudes describe more difficult patient encounters." This same article went on to note that family physicians described patient behaviors (stay sick and demanding) and medical problems (multiple, chronic pain, drug seeking, psychiatric) that they found frustrating. Their management strategies for success in dealing with these were to incorporate collaboration and the appropriate use of power and empathy. Training physicians in doctor-patient interactions and empathy can decrease both the number of and perceived complexity of "difficult" patients, thereby enhancing satisfaction.

The September/October 2008 issue of $7 A B F M$ emphasized medical homes ${ }^{4-7}$ and the November/ December issue focused on diabetes, ${ }^{8-12}$ cardiovascular disease, ${ }^{13-16}$ and obesity. ${ }^{17-20}$ This issue includes many clinical topics. From Israel, we have a trial that suggests the effectiveness of vitamin $B_{12}$ for recurrent aphthous stomatitis; this treatment is safe, and could be tried without significant risk. ${ }^{21}$ We have 3 articles about back pain. Just as vitamin $\mathrm{B}_{12}$ was used in Volkov et al's ${ }^{21}$ study about aphthous stomatitis, Schwalfenberg ${ }^{22}$ provide a case series of using vitamin $\mathrm{D}$ for chronic back pain. This apparently successful case series on chronic low back pain suggests another circumstance in which to check vitamin D levels. I (MAB) have been testing vitamin $\mathrm{D}$ serum levels of more patients with chronic muscle pain or multiple sclerosis and finding many patients need supplementation. Furthermore, Freedman et $\mathrm{al}^{23}$ suggests that when there is excess ongoing pain related to a vertebral compression fracture, consider avascular necrosis of the vertebral body (Kimmel disease). In the third article on back pain, with yet another truism, Deyo et $\mathrm{al}^{24}$ makes a reasoned argument for decreasing our treatment of chronic back pain; more and more is being done (imaging, injections, narcotics, and surgery), yet disability does not lessen. 
Ferris et $\mathrm{al}^{25}$ reported that one-third of men are interested in the human papilloma virus vaccine, with an even larger group undecided. It is heartening that those with risky health behaviors were more, not less, interested in getting the vaccine. On the face of it, human papilloma virus should be an equal opportunity vaccine for both men and women. Shah et $\mathrm{al}^{26}$ present important new findings about portable entertainment use and hearing acuity.

Afonso $^{27}$ reviews the latest information on diagnosing and treating women at high risk for breast cancer. Our diagnostic methods have expanded and our knowledge of the genetics increased, and this review provides clear direction on how to proceed. Most women have a family history of breast cancer that does not much increase risk, so specific patterns of breast cancer in the family should be determined. The article also reviews the important aspects of personal history, mammographic findings, as well as the risk calculators that are available to determine individual risk. Current recommendations on when to order a breast magnetic resonance image for diagnostic testing, sometimes in addition to mammograms, are based on a combination of risk factors. The information about chemoprevention and breast cancer is also very helpful.

Given all the many recent papers and advancing knowledge, Terpening's ${ }^{28}$ review of the use of clopidogrel and aspirin for cardiovascular disease provides clarity and is a useful reference.

We also have case report articles about unusual problems. Lu et $\mathrm{al}^{29}$ describe 3 sore throat patients (all younger than 30 years old), each with Lemierre Syndrome (fusobacteria associated jugular venous thrombosis and septic emboli) from one university family medicine practice within 1 year. Retropharyngeal calcific tendonitis, an entity of which many will not be aware, is described in 2 patients from another academic family medicine center. ${ }^{30}$ Hatch et $\mathrm{al}^{31}$ also describes a case of bullous lesions on a skin graft site.

Shvartzman et al ${ }^{32}$ describe the 30 -year growth in biomedical publishing among Israeli family physicians. Both the similarities and differences of what is known about US family physician authors are interesting. In a 2007 article, Pathman et $\mathrm{al}^{33}$ also described the growth in published research among US family medicine authors. These 2 articles are among a small group of studies demonstrating how the academic and scholarly endeavors in the family medicine specialty are growing despite considerable challenges, such as a great disparity in funding by the National Institutes of Health compared with that received by sub-specialities. ${ }^{34}$

Overall, this is a clinically relevant issue that clarifies burgeoning literature about topics important to family medicine, including the use of vitamins for common clinical problems, recognizing unusual causes of common complaints, and diagnosing and treating women at high risk for breast cancer. Once again, family physicians have much to teach other family physicians from their own practice experiences. No wonder we are generally satisfied with our medical practices and should remain optimistic.

$$
\begin{aligned}
& \text { "Optimist: Person who travels on noth- } \\
& \text { ing from nowhere to happiness." } \\
& \text {-Mark Twain (American humorist, } \\
& \text { writer, and lecturer, 1835-1910) }
\end{aligned}
$$

Marjorie A. Bowman, MD, MPA Anne Victoria Neale, PhD, MPH

\section{References}

1. Pugno PA. Retaining optimism in the face of adversity. J Am Board Fam Med 2009;22:6-8.

2. Katerndahl D, Parchman M, Wood R. Perceived complexity of care, perceived autonomy, and career satisfaction among primary care physicians. J Am Board Fam Med 2009;22:24-33.

3. Elder N, Ricer R, Tobias B. How respected family physicians manage difficult patient encounters. J Am Board Fam Med 2006;19:533-41.

4. Rogers JC. The patient-centered medical home movement-promise and peril for family medicine. J Am Board Fam Med 2008;21:370-4.

5. Rosenthal TC. The medical home: growing evidence to support a new approach to primary care. J Am Board Fam Med 2008;21:427-40.

6. DeVoe JE, Wallace LS, Pandhi N, Solotaroff R, Fryer GE. Comprehending care in a medical home: a usual source of care and patient perceptions about healthcare communication. J Am Board Fam Med 2008;21:441-50.

7. Daaleman TP. The medical home: locus of physician formation. J Am Board Fam Med 2008;21:451-7.

8. Alizadeh Naderi AS, Reilly RF. Primary care approach to proteinuria. J Am Board Fam Med 2008; 21:569-74.

9. Fox CH, Swanson A, Kahn LS, Glaser K, Murray BM. Improving chronic kidney disease care in primary care practices: an upstate New York practice- 
based research network (UNYNET) study. J Am Board Fam Med 2008;21:522-30.

10. Mainous AG, Diaz VA, King DE, Everett CJ, Player MS. The relationship of hepatitis antibodies and elevated liver enzymes with impaired fasting glucose and undiagnosed diabetes. J Am Board Fam Med 2008;21:497-503.

11. Shani M, Taylor TR, Vinker S, et al. Characteristics of diabetics with poor glycemic control who achieve good control. J Am Board Fam Med 2008;21:490-6.

12. Boronat M, García-Delgado Y, Pérez-Martín N, Nóvoa FJ. Severe deterioration of metabolic control caused by malfunction of a disposable insulin pen device. J Am Board Fam Med 2008;21:575-6.

13. Smoley BA, Smith NL, Runkle GP. Hypertension in a population of active duty service members. J Am Board Fam Med 2008;21:504-11.

14. Jackson JH, Sobolski J, Krienke R, Wong KS, FrechTamas F, Nightengale B. Blood pressure control and pharmacotherapy patterns in the United States before and after the release of the Joint National Committee on the Prevention, Detection, Evaluation, and Treatment of High Blood Pressure (JNC 7) guidelines. J Am Board Fam Med 2008;21:512-21.

15. Newman RJ, Darrow M, Cummings DM, et al. Predictive value of exercise stress testing in a family medicine population. J Am Board Fam Med 2008; 21:531-8.

16. Simmons BB, Folsom MA, Bryden LA, Studdiford JS. Angioedema after local trauma in a patient on angiotensin-converting enzyme inhibitor therapy. J Am Board Fam Med 2008;21:577-9.

17. Mathew B, Francis L, Kayalar A, Cone J. Obesity: effects on cardiovascular disease and its diagnosis. J Am Board Fam Med 2008;21:562-8.

18. Davis MM, McGonagle K, Schoeni RF, Stafford F. Grandparental and parental obesity influences on childhood overweight: implications for primary care practice. J Am Board Fam Med 2008;21:549-54.

19. Greenwood JLJ, Murtaugh MA, Omura EM, Alder SC, Stanford JB. Creating a clinical screening questionnaire for eating behaviors associated with overweight and obesity. J Am Board Fam Med 2008;21: 539-48.

20. Fagan HB, Diamond J, Myers R, Gill JM. Perception, intention, and action in adolescent obesity. J Am Board Fam Med 2008;21:555-61.
21. Volkov I, Rudoy I, Freud T, et al. Effectiveness of vitamin B12 in treating recurrent aphthous stomatitis: a randomized, double-blind, placebo-controlled trial. J Am Board Fam Med 2009;22:9-16.

22. Schwalfenberg G. Improvement of chronic back pain or failed back surgery with vitamin $\mathrm{D}$ repletion: a case series. J Am Board Fam Med 2009;22:69-74.

23. Freedman BA, Heller JG. Kummel disease: a not-sorare complication of osteoporotic vertebral compression fractures. J Am Board Fam Med 2009;22:75-8.

24. Deyo RA, Mirza SK, Turner JA, Martin BI. Overtreating chronic back pain: time to back off? J Am Board Fam Med 2009;22:62-8.

25. Ferris DG, Waller JL, Miller J, et al. Variables associated with human papillomavirus (HPV) vaccine acceptance by men. J Am Board Fam Med 2009;22: 34-42.

26. Shah S, Gopal B, Reis J, Novak M. Hear today, gone tomorrow: an assessment of portable entertainment player use and hearing acuity in a community sample. J Am Board Fam Med 2009;22:17-23.

27. Afonso N. Women at high risk for breast cancerwhat the primary care provider needs to know. J Am Board Fam Med 2009;22:43-50.

28. Terpening C. An appraisal of dual antiplatelet therapy with clopidogrel and aspirin for prevention of cardiovascular events. J Am Board Fam Med 2009; 22:51-6.

29. Lu MD, Vasavada Z, Tanner C. Lemierre syndrome following oropharyngeal infection: a case series. J Am Board Fam Med 2009;22:79-83.

30. Razon RVB, Nasir A, Wu GS, Soliman M, Trilling J. Retropharyngeal calcific tendonitis: report of two cases. J Am Board Fam Med 2009;22:84-8.

31. Orvis AK, Ihnatsenka V, Hatch RL. Bullous lesions on a skin graft donor site. J Am Board Fam Med 2009;22:89-92.

32. Pshetizky Y, Tandeter H, Tabenkin H, et al. Thirty years of family medicine publications in Israel (19752004): what, where, and how much? J Am Board Fam Med 2009;22:57-61.

33. Pathman DE, Viera AJ, Newton WP. Research published in 2003 by U.S. family medicine authors. J Am Board Fam Med 2008;21:6-16.

34. Hueston WJ. Research activity in family medicine: the "best of times" or "can I have more, please"? J Am Board Fam Med 2008;21:4-5. 